\title{
Clinical and biological significance of RAD51 expression in breast cancer: a key DNA damage response protein
}

\author{
Alaa Tarig Alshareeda ${ }^{1,2}$, Ola H Negm ${ }^{3} 4^{*}$, Mohammed A Aleskandarany ${ }^{1,5}$, Andrew R. Green ${ }^{1}$, Christopher \\ Nolan $^{1}$, Patrick J Tighe ${ }^{3}$, Srinivasan Madhusudan ${ }^{1}$, Ian O. Ellis ${ }^{1}$, Emad A. Rakha ${ }^{1}$ \\ ${ }^{1}$ Division of Cancer and Stem Cells, School of Medicine, The University of Nottingham and Nottingham \\ University Hospitals NHS Trust, Nottingham City Hospital, Nottingham, UK. ${ }^{2}$ King Abdullah International \\ Medical Research Center, Riyadh, KSA. ${ }^{3}$ Immunology, University of Nottingham, School of Life Sciences, UK, \\ ${ }^{4}$ Medical Microbiology and Immunology Department, Faculty of Medicine, Mansoura University, Egypt. \\ ${ }^{5}$ Pathology Department, Menofia Faculty of Medicine, Egypt.
}

*First joint author

\section{Correspondence:}

\section{Dr Emad Rakha}

Division of Cancer and Stem Cells, School of Medicine, The University of Nottingham and Nottingham University Hospitals NHS Trust, Nottingham City Hospital, Nottingham, UK, NG5 1PB.

Key words: RAD51, immunohistochemistry, DNA repair, DNA damage response, BRCAmutated breast cancers, reverse phase protein array. 


\section{ABSTRACT}

Purpose: Impaired DNA-damage response (DDR) may play a fundamental role in the pathogenesis of breast cancer (BC). RAD51 is key player in DNA double strand break repair. In this study, we aimed to assess the biological and clinical significance of RAD51 expression with relevance to different molecular classes of BC and patients' outcome.

Methods: The expression of RAD51 was assessed immunohistochemically in a wellcharacterised annotated series $(n=1184)$ of early-stage invasive BC with long-term follow-up. A subset of cases of $\mathrm{BC}$ from patients with known BRCA1 germline mutations was included as a control group. The results were correlated with clinicopathological and molecular parameters and patient outcome. RAD51 protein expression level was also assayed in a panel of cell lines using reverse phase protein array (RPPA).

Results: RAD51 was expressed in the nuclei $(\mathrm{N})$ and cytoplasm $(\mathrm{C})$ of malignant cells. Subcellular co-localisation phenotypes of RAD51 were significantly associated with clinicopathological features and patient outcome. Cytoplasmic expression (RAD51C ${ }^{+}$) and lack of nuclear expression ( $\mathrm{RAD} 51 \mathrm{~N}^{-}$) were associated with features of aggressive behaviour including larger tumour size, high grade, lymph nodal metastasis, basal-like, and triplenegative phenotypes, together with aberrant expression of key DDR biomarkers including BRCA1. All BRCA1 mutated tumours had RAD $51 \mathrm{C}^{+} / \mathrm{N}^{-}$phenotype. RPPA confirmed IHC results and showed differential expression of RAD51 in cell lines based on ER expression and $B R C A 1$ status. RAD51N ${ }^{+}$and $\mathrm{RAD} 1 \mathrm{C}^{+}$tumours were associated with longer and shorter breast cancer specific survival (BCSS), respectively. The RAD51N ${ }^{+}$was an independent predictor of longer BCSS $(\mathrm{P}<0.0001)$.

Conclusions: lack of RAD51 nuclear expression is associated with poor prognostic parameters and shorter survival in invasive BC patients. The significant associations between RAD51 subcellular localisation and clinicopathological features, molecular subtype and patients' outcome suggest that the trafficking of DDR proteins between the nucleus and cytoplasm might play a role in the development and progression of BC. 


\section{INTRODUCTION}

RAD51 plays a major role in homologous recombination (HR) of DNA during double strand break (DSB) repair. Of the various types of DNA damage that occur within a mammalian cell, DSB is recognised as the most lethal $[1,2]$. Many studies have indicated a link between DSB and genomic instability and cancer $[1,3]$. Repair of DSB can be achieved through one of two overlapping pathways: homologous recombination (HR) and non-homologous end joining (NHEJ) pathways [4]. The main difference between these two pathways lies in the requirement of a homologous DNA template during the repair process [1]. In HR, RAD51 is involved in the search for homology and strand pairing stages of the process. Unlike other proteins involved in DNA damage repair, RAD51 forms a helical nucleoprotein filament on DNA. A single strand of DNA is coated by RAD51 to form a nucleoprotein filament that penetrates and makes pairs with a homologous region in duplex DNA, leading to the activation of strand exchange and the creation of a crossover between the juxtaposed DNA [5, 6]. Importantly, BRCA1 co-localises with RAD51 to form a complex [7, 8]. This was evidenced by the reduced formation of RAD51 after treatment with DNA-damaging agents and during HR in BRCAl-deficient cells [9]. Moreover, previous studies have demonstrated that HR is defective in BRCA1-deficient cells [10]. RAD51 may also be required for NHEJ pathway of DSB repair interacting with the single strand DNA-binding proteins such as BRCA2, PALB2 and RAD52 [11].

Several studies have indicated that RAD51 nuclear expression is increased in metastatic mammary carcinoma, indicating that it may play an important role in the mammary carcinogenesis [12-15]. However, an increased risk of distant metastasis occurs with an increased cytoplasmic expression of RAD51 [16] and RAD51 nuclear foci are inversely associated with tumour response to chemotherapy [17]. 
The aim of this study is to investigate the expression of RAD51 in a large, well-characterised clinically and molecularly annotated series of early stage sporadic BC using immunohistochemistry to determine the association between RAD51 and clinicopathological and molecular features and clinical outcome. A series of $B R C A$ mutated $\mathrm{BC}$ was used as a control group for tumours with deficient HR pathway. In addition, reverse phase protein assay (RPPA) was used to quantify RAD51 protein expression in cell lines representing different BC molecular classes. 


\section{MATERIALS AND METHODS}

\section{Study Cohort}

A well-characterised cohort of unselected primary operable invasive BC $(n=1,184)$ derived from the Nottingham Tenovus primary breast carcinoma series from female patients presenting between 1989 and 1998 formed the material of this study. In addition, a group of BRCA1 germline mutation carrier ( $\mathrm{n}=18$ cases) were also studied. Data relating to patients' clinicopathological features were available including patients' age, menopausal status, primary tumour size, histological tumour type, tumour grade, axillary nodal status, lymphovascular invasion and Nottingham Prognostic Index (NPI) [18, 19]. Survival data were available and prospectively maintained, including development of locoregional, distant recurrences, and breast cancer related mortality. The median follow-up time of the sporadic BC series was 177 months (range $=1-308$ months) and of the $B R C A 1$ mutated series was 93 months (range $=9-274$ months). Using these outcome data, BC specific survival (BCSS) was calculated, using appropriate statistical tests, as the time (in months) from the date of primary surgery to the time of death because of BC.

Patients in these series were managed in accordance to a standard uniform protocol based on patients' and tumour characteristics; NPI and ER status, and menopausal status [19]. Patients within the excellent NPI prognostic group (score $\leq 3.4)$ received no adjuvant therapy, but those patients with NPI> 3.4 received Tamoxifen if ER-positive $(+/-$ Zoladex in case the patients were pre-menopausal). On the other hand, classical cyclophosphamide, methotrexate and 5-flurouracil (CMF) were used if the patients were ER-negative and fit to receive chemotherapy.

Data on the following biomarkers were available: ER, progesterone receptor (PgR), HER-2, DNA damage response proteins (BRCA1, BARD1, KU70/KU80, DNA-PKcs, PIAS1, and 
CHK1), basal cytokeratins [CK5, CK14, and CK17], and proliferation and cell-cycle associated proteins (Ki67, and P53). In this series, HER2 was assessed using IHC (DAKO) and dual-colour chromogenic in-situ hybridisation (CISH) as previously published [20]. Ki67 labelling index (Ki67LI) was assessed on full-face tumour tissue sections and was assessed as the percentage of Ki67 positive cells among a total number of 1000 malignant cells at high power magnification (x400) [20]. Supplementary table 1 displays sources, dilution, cut-off point and pre-treatment conditions used of the antibodies of DNA damage sensing and repair markers used in this study. The staining conditions as well as data dichotomy of other markers in this study were defined as previously described [18-22]. This study was approved by Nottingham Research Ethics Committee 2.

\section{Immunohistochemistry}

Immunohistochemistry was carried out using the Novolink Kit-polymer detection system (Leica, Newcastle, UK). Antigen retrieval was performed in citrate buffer solution $(\mathrm{pH}=6)$ using microwave heating for 20 minutes. Anti-RAD51 primary antibody was used (clone Ab88572, Abcam Ltd., Cambridge, UK) optimally diluted at 1:70 and incubated for 60 minutes at room temperature. Freshly prepared 3-3'Diam-inobenzidine tetrahydrochloride (Novolink DAB substrate buffer plus) was used as a chromogen for reaction visualisation. The stained TMA sections were counter stained with haematoxylin for 6 minutes [22].

\section{Scoring of RAD51 immunohistochemical staining}

High-resolution digital images (Nanozoomer; Hamamatsu Photonics, Welwyn Garden City, UK) scanned at $x 20$ magnification was used to facilitate the visual scoring of the TMA cores via web based interface (Distiller; Slidepath, Ltd., Dublin, Ireland). Only immunostaining of invasive $\mathrm{BC}$ cells within the tissue cores was considered as positive. The semi-quantitative 
modified histochemical score (H score) was used to assess RAD51 staining [23]. Thirty percent of the stained RAD51 TMA cores were re-scored by another observer and statistical agreement between the two scores was calculated using inter-rater Kappa statistic (Table 1).

\section{Antibody specificity and Reverse Phase Protein Microarray (RPPA)}

To test the specificity of the used antibody and to confirm the expression of RAD51 in specific $\mathrm{BC}$ cell lines corresponding to molecular classes of BC, Western blotting and RPPA were performed as previously described [24-26]. Four different cell lines were used; luminal phenotype MCF-7 cell lines (characterised by positive expression of ER and BRCA1, ATCC) and MDA-MB-436 (ER- and EGFR+, CLS) which were grown in RPMI1640 (Sigma, UK). In addition, BRCA1 deficient HeLaSilenciX® cells and control BRCAl proficient HeLaSilenciX® cells (Tebu-Bio) which were grown in DMEM medium (Life Technologies).

For Western blotting, the anti-RAD51 primary antibody (clone Ab88572, Abcam Ltd., Cambridge, UK) was used (1:1000, and incubated for 1 hour at room temperature). The reaction was developed using Enhanced Chemiluminescence substrate (GE Healthcare Life Sciences, Buckinghamshire, UK). For RPPA, RAD51 (1:100 in a reducing background DAKO antibody diluent). In addition, GAPDH (BioLegend, 1:250 in the same diluent), was used as a house-keeping protein to control protein loading. Protein signals were determined with background subtraction and normalization to the internal housekeeping protein using RPPanalyzer, a module within the $\mathrm{R}$ statistical language on the CRAN (http://cran.rproject.org/) [27].

\section{Statistical Analysis}

All statistical analyses were performed using SPSS 21.0 statistical software (SPPS Inc., Chicago, IL, USA). For optimal RAD51 cut-off point determination, X-tile bioinformatics 
software was used (version 3.6.1, 2003-2005, Yale University, USA) [28]. Correlations of categorical variables were carried out with Chi-Squared test $\left(x^{2}\right)$. One-way ANOVA was applied to compare the level of RAD51 expression among different BC classes for IHC and RPPA data, with pairwise differences assessment using the post-hoc test. Associations with patients' outcome were assessed using Kaplan-Meier curves and log rank test. A two-sided Pvalue of $<0.01$ was considered statistically significant. 


\section{RESULTS}

\section{Expression of RAD51 in Invasive Breast Cancer}

The specificity of RAD51 antibody was confirmed by Western blotting as demonstrated by single band at the correct protein size (Figure 1, panel A). Using immunohistochemistry, RAD51 expression was localised to nuclei and cytoplasm of the malignant cells with no membrane staining (Figure 1, panel II). For analytical purposes, RAD51 H-score was categorised using X-tile software. The cut-off points used for nuclear RAD51 expression positive was $\geq 10 \mathrm{H}$-score, and for RAD51 cytoplasmic expression was $\geq 80 \mathrm{H}$-score (Table 1). Expression of RAD51 varied among BC molecular classes based on the status of $B R C A 1$ and hormone receptor expression (Figure 1, panel III). There was a strong expression of nuclear RAD51 in the sporadic ER positive and BRCA1 positive class compared to ER negative and BRCA1 negative sporadic and hereditary BC classes $(\mathrm{P}<0.0001$ and $\mathrm{P}=0.0001$, respectively).

\section{Association between RAD51 and clinicopathological features}

Sub-cellular expression of RAD51 was distinctively associated with clinicopathological features: cytoplasmic expression was positively associated while nuclear expression was negatively associated with features characteristics of aggressive behaviour. Therefore, further analyses were carried out following classification of BC based on subcellular co-localisation into four groups: double negative expression group [cytoplasmic (C) and nuclear $(\mathrm{N})$ negative, $\left(\mathrm{C}^{-} / \mathrm{N}^{-}\right), 6.1 \%$, double positive $\left(\mathrm{C}^{+} / \mathrm{N}^{+}\right), 29.8 \%$, and single positive expression groups $\left(\mathrm{C}^{+} / \mathrm{N}^{-}\right.$and $\left.\mathrm{C}^{-} / \mathrm{N}^{+}\right), 59.4 \%$ and $4.7 \%$, respectively. RAD51 combinatorial expression showed significant associations with poor prognostic features such as larger tumour size, higher grade with nuclear pleomorphism, and frequent mitotic figures (Table $1, \mathrm{P}<0.0001$ ). It 
was observed that up to $75 \%$ of $\mathrm{RAD} 51 \mathrm{C}^{+} / \mathrm{N}^{-}$group were of large tumour size $(>2 \mathrm{~cm})$ and of grade 3 tumours.

\section{Association of RAD51 expression and expression of other biomarkers}

Table 2 summarises the associations between RAD51 subcellular co-localisation groups and other key DNA-damage repair markers. The $\mathrm{RAD} 51 \mathrm{C}^{+} / \mathrm{N}^{-}$phenotype showed significant association with lack of nuclear and positive cytoplasmic expression of DNA-DSB biomarkers BRCA1, $\gamma \mathrm{H} 2 \mathrm{AX}, \mathrm{CHK} 1$ and MTA1, cytoplasmic expression of BARD1 and SMC6L1 and expression of CHK2, ATM, PTEN, the BRCA1 inhibitor ID4 and the NHEJ biomarkers KU70/KU80 and DNA-PKcs regardless of their subcellular localisation.

The association between RAD51 subcellular localisation combinatorial groups and other tissue biomarkers is summarised in Table 3 where $\mathrm{RAD} 51 \mathrm{C}^{+} / \mathrm{N}^{-}$subgroup showed significant association with lack of hormone receptor $\left(\mathrm{ER}^{-}\right.$and $\left.\mathrm{PgR}^{-}\right)$, triple negative and basal-like $\left(\mathrm{BLBC}^{+}\right)$phenotypes, Ck5/6+, and high Ki67LI $(\mathrm{P}<0.0001)$. In addition, RAD51 showed significant association with the cell cycle progression/arrest regulator markers P53 and P27 $(\mathrm{P}<0.0001)$. Furthermore, There was a significant association between the nucleocytoplasmic transport marker KPNA2 expression and $\mathrm{RAD}_{10} \mathrm{C}^{+} / \mathrm{N}^{-}(\mathrm{P}<0.0001)$.

\section{Expression of RAD51 in Cell Lines by Reverse Phase Protein Microarray}

Figure 4 displays the expression of RAD51 in different cell lines using RPPA. RPPA showed results consistent with RAD51 nuclear expression by IHC and demonstrated a significantly higher level of expression of RAD51 in the HeLa BRCA1 control (BRCAl+ wild type) and MCF-7 cell lines $\left(\mathrm{ER}^{+}, \mathrm{BRCA} 1^{+}\right)$, when compared with the BRCAl deficient HeLa, or MDAMB-436 (ER- \& BRCA1) cell lines. 


\section{Relationship between RAD51 and patient outcome}

Negative nuclear expression of RAD51 demonstrated significantly shorter BCSS $(\mathrm{P}<0.01)$ with a $67 \%$ ten-years survival rate compared to $82 \%$ in the RAD51 nuclear positive cases, Figure 2A. Cytoplasmic expression $\left(\mathrm{RAD}_{1 \mathrm{C}}{ }^{+}\right)$showed a trend for shorter $\mathrm{BCSS}(\mathrm{P}=0.02$, Figure $2 \mathrm{~B}$ ). Furthermore, the $\mathrm{RAD} 51 \mathrm{C}^{+} / \mathrm{N}^{-}$phenotype had the shortest $\mathrm{BCSS}$, in comparison with other subcellular combinations (Figure $2 \mathrm{C}$; RAD51C ${ }^{+} / \mathrm{N}^{+}, \mathrm{RAD} 51 \mathrm{C}^{-} / \mathrm{N}^{-}$and $\mathrm{RAD} 51 \mathrm{C}^{-}$ $\left./ \mathrm{N}^{+}, \mathrm{P}<0.01\right)$. In regards to chemotherapy, patients with $\mathrm{RAD} 51 \mathrm{~N}^{+}$tumours who did not receive adjuvant chemotherapy showed the best $\mathrm{BCSS}(\mathrm{P}=0.02)$, whereas the other groups were not significantly different from each other, Figure 3 . Within the primary invasive BC series, cox proportional hazard regression analyses for predictors of BCSS showed that RAD51N+ was an independent predictor of longer BCSS ( $\mathrm{P}<0.01$, hazard ratio (HR), 0.73, 95\% confidence interval $(\mathrm{CI})=0.56-0.96)$. However, at the RAD51 nucleocytoplasmic expression groups showed non- significant association with survival $(\mathrm{P}=0.08, \mathrm{HR}=1.18$, $95 \% \mathrm{CI}=0.98-1.42)$, Table 4. 


\section{DISCUSSION}

The mechanisms of DNA damage repair play a crucial role in the maintenance of DNA integrity to ensure high-fidelity transmission of genetic information. Therefore, inability to respond or repair DNA damage leads to genetic instability and enhancement of cancer development $[1,2]$. The deficiencies in HR pathway, with BRCA1 and RAD51 as key markers, result in a marked increase in the risk of early onset of breast, ovarian and other cancers [29]. RAD51 is essential for genetic recombination and DNA repair as it has the ability to promote joint molecule formation and DNA strand exchange between homologous DNA molecules [6, 30, 31]. RAD51 binds to DNA forming highly ordered nucleoprotein filaments in which the DNA is encased within a protein sheath [32].

In this study the role of RAD51, with particular attention to DDR and patients' outcome, was evaluated using immunohistochemistry in a large clinically annotated series of unselected early-stage sporadic $\mathrm{BC}$ cases and a small cohort of BRCAl germline mutation BC cases.. Our results showed that the expression of RAD51 is both nuclear and cytoplasmic and it varies among $\mathrm{BC}$ molecular classes based on the status of $B R C A 1$ and hormone receptor expression with low nuclear expression observed in BRCA1-assoicated tumours and in sporadic tumours lacking ER and BRCA1 expression. Low levels of nuclear RAD51 were associated with established poor prognostic factors, such as high histological grade, TN phenotype and shorter patients' survival; findings reported by other investigators [33].

Our results also indicate that tumours lacking nuclear RAD51 overexpress other proteins involved in the alternative DDR pathways including NHEJ as supported by the high level of expression of NHEJ proteins KU70/KU80 and DNA-PKcs. Consistent with a previous study [34], the IHC results of RAD51 in our series of BC confirmed a direct relationship between 
high cytoplasmic RAD51 expression and TN status, while the opposite was observed with RAD51 nuclear expression. This finding suggests the possible role of steroid hormone receptors in the regulation of RAD51 [35]. Pedram and co-workers reported an inhibition of ATR signalling by oestradiol (E2), which produced a delay in the formation of RAD51 nuclear foci following UV-irradiation [36]. Overall, absence of steroid hormone receptors may be a surrogate marker of E2/ER signalling, which may directly influence the DNA-DSB repair pathway [37, 38].

Interestingly, in the results presented herein, a comparison of the RAD51 nuclear and cytoplasmic expression arising within BRCAl mutation carriers showed high levels of cytoplasmic RAD51. This supports the hypothesis that nuclear levels of RAD51 may be lower due to the mutation of $B R C A 1$, which might inhibit the protein transfer into the nucleus. This observation has previously been reported in prostate cancer [39]. RAD51 is similar to other DDR proteins where its cytoplasmic sequestration seems to represent lack of functional phenotype [40]. Our findings demonstrate the importance of the nucleocytoplasmic transport protein KPNA2 on the subcellular localisation of RAD51. High level of KPNA2 nuclear expression is associated with cytoplasmic localisation of RAD51. Although KPNA2 is a nuclear import protein [41, 42], high nuclear accumulation of KPNA2 leads to cytoplasmic retention of nuclear localisation sequence (NLS)-containing cargo proteins due to defective import [43]. RAD51 cyto-nuclear transport is an essential aspect of the cellular response to DNA damage [44]. Nuclear localisation of KPNA2 in cancer is thought to be due to cellular stress and some authors have demonstrated that the nuclear retention of KPNA2 in response to cellular stress suppresses the nuclear import [45]. 
In cancer cell lines with a HR defect, such as $B R C A 1$ or $B R C A 2$ loss, the cells are unable to stimulate foci of RAD51 following DNA damage [33, 46] leading to a functional readout of a defect in HR. in this study, for quantitative expression of RAD51 in relation to molecular class of BC and other DDR proteins, RAD51 was assessed in different BC cell lines using RPPA. The results obtained by IHC and RPPA revealed lower levels of RAD51 in the HeLa BRCA1 cell line (BRCA1 deficient), or known BRCAl mutation BC cases/ER- BC, than the control HeLa BRCA1 cell line (BRCA1 proficient) or sporadic BC showing positive BRCA1 and ER. This finding may propose a defect in the HR pathway in BRCAl mutation cases/or ER negative sporadic BC. The RPPA findings were in line with the nuclear RAD51 IHC expression, although RRPA picked up both cytoplasmic and nuclear expression. This highlights the advantage of determining the subcellular localisation as assessed by IHC.

The link between loss of PTEN and defective DNA-DSB repair has been previously studied. PTEN works on chromatin and controls the expression of RAD51, which usually decreases the incidence of spontaneous DSBs. Accordingly, PTEN-deficient cells have defective DNADSB repair, possibly due to loss or down regulation of RAD51, in addition to loss of PTEN at centromeres [47]. In the present study, $\mathrm{RAD} 51 \mathrm{C}^{+} / \mathrm{N}^{-}$expression localisation was associated with loss of PTEN. These findings may indicate a role for PTEN involvement in HR of DNA repair.

Both CHK1 and CHK2 are essential kinases for the repair of DNA and are important in the recruitment of the functional associations between BRCA1 and RAD51 proteins; thus, they increase the HR-mediated repair of stalled replication forks [48]. CHK1 phosphorylates RAD51 and other proteins, such as FANCD2, in order to promote the repair pathways of DNA [49]. In this study, there was a significant positive association between $\mathrm{CHK} 1 \mathrm{~N}$, but not 
cytoplasmic expression, and RAD51N expression. Moreover, nuclear CHK2 expression showed a positive association with the cytoplasmic and a negative association with the RAD51 nuclear expression. Cases exhibiting low nuclear CHK1 and high cytoplasmic expression or CHK2 might hypothetically have a deficiency in response to DNA damage, leading to a further aggressive tumour. Bahassi et al investigated the functional associations between BRCA2 and RAD51 in response to DNA damage and its regulation by CHK1 or CHK2. In UV-treated cells, the CHK1 depletion from cells using siRNA produces a complete loss of RAD51 localisation to nuclear foci with subsequent replication block [50]. Conversely, cells of truncated and non-functional CHK2 have no obvious defect in localisation at the foci of RAD51, suggesting that CHK1 is a key member in controlling BRCA2-RAD51 interaction in response to replication block. Cells lacking CHK2 display a noticeable impairment in RAD51 localisation instantly after DNA-DSB, as induced by ionising radiation treatment $[50]$.

Nuclear over-expression of RAD51 protein in patients treated with adjuvant chemotherapy was associated with a shorter BCSS compared to those who did not receive chemotherapy. In line with these findings, it has been reported that the formation of RAD51 foci in response to DNA damage is related to the response to neoadjuvant anthracycline-based chemotherapy in BC [33]. This could be explained by the ability of the chemotherapeutic agents to bind to DNA producing cross-links in addition to triggering cell death through the induction of DSBs [51]. This could suggest that a defect in the HR pathway may be responsible for failure to repair damage caused by these agents, with subsequent activation of the error-prone backup NHEJ pathways to repair DNA [52-54]. 


\section{CONCLUSIONS:}

The significant associations between RAD51 subcellular localisation and clinicopathological and molecular features and outcome suggest that the cyto-nuclear trafficking of DDR proteins might play a role in BC development and progression. Differential expression of RAD51 based on hormone receptor and BRCA1 status as observed using IHC is noted in both sporadic and hereditary $\mathrm{BC}$ and is demonstrated on cell lines using RPPA. Investigating large panel of biomarkers involved in the different pathways of DDR is likely to improve our understanding of the complex DDR mechanisms in BC.

Conflict of Interest: The authors have no conflict of interest to declare. 


\section{REFERENCES}

1. Khanna KK, Jackson SP (2001) DNA double-strand breaks: signaling, repair and the cancer connection. Nat Genet, 27(3):247-254.

2. van Gent DC, Hoeijmakers JH, Kanaar R (2001) Chromosomal stability and the DNA double-stranded break connection. Nat Rev Genet, 2(3):196-206.

3. Pierce AJ, Stark JM, Araujo FD, Moynahan ME, Berwick M, Jasin M (2001) Double-strand breaks and tumorigenesis. Trends Cell Biol, 11(11):S52-59.

4. Powell SN, Kachnic LA (2003) Roles of BRCA1 and BRCA2 in homologous recombination, DNA replication fidelity and the cellular response to ionizing radiation. Oncogene, 22(37):5784-5791.

5. Sung P (1994) Catalysis of ATP-dependent homologous DNA pairing and strand exchange by yeast RAD51 protein. Science, 265(5176):1241-1243.

6. Baumann P, Benson FE, West SC (1996) Human Rad51 protein promotes ATPdependent homologous pairing and strand transfer reactions in vitro. Cell, 87(4):757-766.

7. Chen J, Silver DP, Walpita D, Cantor SB, Gazdar AF, Tomlinson G, Couch FJ, Weber BL, Ashley T, Livingston DM et al (1998) Stable interaction between the products of the BRCA1 and BRCA2 tumor suppressor genes in mitotic and meiotic cells. Mol Cell, 2(3):317-328.

8. Scully R, Chen J, Plug A, Xiao Y, Weaver D, Feunteun J, Ashley T, Livingston DM (1997) Association of BRCA1 with Rad51 in mitotic and meiotic cells. Cell, 88(2):265-275.

9. Venkitaraman AR (2001) Functions of BRCA1 and BRCA2 in the biological response to DNA damage. J Cell Sci, 114(Pt 20):3591-3598.

10. Moynahan ME, Chiu JW, Koller BH, Jasin M (1999) Brca1 controls homologydirected DNA repair. Molecular cell, 4(4):511-518.

11. Bau DT, Mau YC, Shen CY (2006) The role of BRCA1 in non-homologous endjoining. Cancer Lett, 240(1):1-8.

12. Klopfleisch R, Gruber AD (2009) Increased expression of BRCA2 and RAD51 in lymph node metastases of canine mammary adenocarcinomas. Veterinary pathology, 46(3):416-422.

13. Klopfleisch R, Schutze M, Gruber AD (2010) RAD51 protein expression is increased in canine mammary carcinomas. Veterinary pathology, 47(1):98-101.

14. Wiegmans AP, Al-Ejeh F, Chee N, Yap PY, Gorski JJ, Da Silva L, Bolderson E, Chenevix-Trench G, Anderson R, Simpson PT et al (2014) Rad51 supports triple negative breast cancer metastasis. Oncotarget, 5(10):3261-3272.

15. Hu J, Wang N, Wang YJ (2013) XRCC3 and RAD51 expression are associated with clinical factors in breast cancer. PLoS One, 8(8):e72104. 
16. Sosinska-Mielcarek K, Duchnowska R, Winczura P, Badzio A, Majewska H, Lakomy J, Peksa R, Pieczynska B, Radecka B, Debska S et al (2013) Immunohistochemical prediction of brain metastases in patients with advanced breast cancer: the role of Rad51. Breast, 22(6):1178-1183.

17. Asakawa $\mathrm{H}$, Koizumi $\mathrm{H}$, Koike A, Takahashi $\mathrm{M}$, Wu W, Iwase $\mathrm{H}$, Fukuda $\mathrm{M}$, Ohta $\mathrm{T}$ (2010) Prediction of breast cancer sensitivity to neoadjuvant chemotherapy based on status of DNA damage repair proteins. Breast Cancer Res, 12(2):R17.

18. Alshareeda AT, Negm OH, Albarakati N, Green AR, Nolan C, Sultana R, Madhusudan S, Benhasouna A, Tighe P, Ellis IO et al (2013) Clinicopathological significance of KU70/KU80, a key DNA damage repair protein in breast cancer. Breast Cancer Res Treat, 139(2):301-310.

19. Rakha EA, Putti TC, Abd El-Rehim DM, Paish C, Green AR, Powe DG, Lee AH, Robertson JF, Ellis IO (2006) Morphological and immunophenotypic analysis of breast carcinomas with basal and myoepithelial differentiation. J Pathol, 208(4):495-506.

20. Aleskandarany MA, Green AR, Benhasouna AA, Barros FF, Neal K, Reis-Filho JS, Ellis IO, Rakha EA (2012) Prognostic value of proliferation assay in the luminal, HER2-positive, and triple-negative biologic classes of breast cancer. Breast Cancer Res, 14(1):R3.

21. Rakha EA, Elsheikh SE, Aleskandarany MA, Habashi HO, Green AR, Powe DG, ElSayed ME, Benhasouna A, Brunet JS, Akslen LA et al (2009) Triple-negative breast cancer: distinguishing between basal and nonbasal subtypes. Clin Cancer Res, 15(7):2302-2310.

22. Alshareeda AT, Rakha EA, Nolan CC, Ellis IO, Green AR (2012) Fatty acid binding protein 7 expression and its sub-cellular localization in breast cancer. Breast Cancer Res Treat, 134(2):519-529.

23. McCarty Jr KS, Miller LS, Cox EB, et al (1985) Estrogen receptor analyses: Correlation of biochemical and immunohistochemical methods using monoclonal antireceptor antibodies. Arch Pathol Lab Med, 109: 716-721.

24. Alshareeda AT, Negm OH, Albarakati N, Green AR, Nolan C, Sultana R, Madhusudan S, Benhasouna A, Tighe P, Ellis IO et al (2013) Clinicopathological significance of KU70/KU80, a key DNA damage repair protein in breast cancer. Breast Cancer Res Treat, 139(2):301-310.

25. Alshareeda AT, Negm OH, Green AR, Nolan C, Tighe P, Albarakati N, Sultana R, Madhusudan S, Ellis IO, Rakha EA (2014) SUMOylation proteins in breast cancer. Breast Cancer Res Treat, 144(3):519-530.

26. Negm OH, Mannsperger HA, McDermott EM, Drewe E, Powell RJ, Todd I, Fairclough LC, Tighe PJ (2014) A pro-inflammatory signalome is constitutively activated by $\mathrm{C} 33 \mathrm{Y}$ mutant TNF receptor 1 in TNF receptor-associated periodic syndrome (TRAPS). Eur J Immunol, 44(7):2096-2110.

27. Mannsperger HA, Gade S, Henjes F, Beissbarth T, Korf U (2010) RPPanalyzer: Analysis of reverse-phase protein array data. Bioinformatics, 26(17):2202-2203. 
28. Camp RL, Dolled-Filhart M, Rimm DL: X-Tile: A New Bio-Informatics Tool for Biomarker Assessment and Outcome-Based Cut-Point Optimization. In., vol. 10; 2004: 7252-7259.

29. Jackson SP, Bartek J (2009) The DNA-damage response in human biology and disease. Nature, 461(7267):1071-1078.

30. Benson FE, Stasiak A, West SC (1994) Purification and characterization of the human Rad51 protein, an analogue of E. coli RecA. Embo J, 13(23):5764-5771.

31. Gupta RC, Bazemore LR, Golub EI, Radding CM (1997) Activities of human recombination protein Rad51. Proc Natl Acad Sci U S A, 94(2):463-468.

32. McIlwraith MJ, Van Dyck E, Masson JY, Stasiak AZ, Stasiak A, West SC (2000) Reconstitution of the strand invasion step of double-strand break repair using human Rad51 Rad52 and RPA proteins. J Mol Biol, 304(2):151-164.

33. Graeser M, McCarthy A, Lord CJ, Savage K, Hills M, Salter J, Orr N, Parton M, Smith IE, Reis-Filho JS et al (2010) A marker of homologous recombination predicts pathologic complete response to neoadjuvant chemotherapy in primary breast cancer. Clin Cancer Res, 16(24):6159-6168.

34. Barbano R, Copetti M, Perrone G, Pazienza V, Muscarella LA, Balsamo T, Storlazzi CT, Ripoli M, Rinaldi M, Valori VM (2011) High RAD51 mRNA expression characterize estrogen receptor-positive/progesteron receptor-negative breast cancer and is associated with patient's outcome. International journal of cancer, 129(3):536-545.

35. Barbano R, Copetti M, Perrone G, Pazienza V, Anna Muscarella L, Balsamo T, Tiziana Storlazzi C, Ripoli M, Rinaldi M, Maria Valori V (2010) High RAD51 mRNA expression characterize estrogen receptorâ€ $\square$ positive/progesteron receptorâ€ $\square$ negative breast cancer and is associated with patient's outcome. International Journal of Cancer.

36. Pedram A, Razandi M, Evinger AJ, Lee E, Levin ER (2009) Estrogen inhibits ATR signaling to cell cycle checkpoints and DNA repair. Molecular biology of the cell, 20(14):3374-3389.

37. Arpino $G$, Weiss $H$, Lee AV, Schiff $R$, De Placido $S$, Osborne CK, Elledge RM (2005) Estrogen receptorâ€"positive, progesterone receptorâ€"negative breast cancer: association with growth factor receptor expression and tamoxifen resistance. Journal of the National Cancer Institute, 97(17):1254-1261.

38. Yamamori T, Meike S, Nagane M, Yasui H, Inanami O (2013) ER stress suppresses DNA double-strand break repair and sensitizes tumor cells to ionizing radiation by stimulating proteasomal degradation of Rad51. FEBS letters, 587(20):3348-3353.

39. Mitra A, Jameson C, Barbachano Y, Sanchez L, Koteâ€ $\square$ Jarai Z, Peock S, Sodha N, Bancroft E, Fletcher A, Cooper C (2009) Overexpression of RAD51 occurs in aggressive prostatic cancer. Histopathology, 55(6):696-704.

40. Dubey A, Chouhan U (2011) Subcellular Localization of Proteins. Archives of Applied Science Research, 3(6):392-401. 
41. Zannini L, Lecis D, Lisanti S, Benetti R, Buscemi G, Schneider C, Delia D (2003) Karyopherin-alpha2 protein interacts with $\mathrm{Chk} 2$ and contributes to its nuclear import. J Biol Chem, 278(43):42346-42351.

42. Huang L, Wang HY, Li JD, Wang JH, Zhou Y, Luo RZ, Yun JP, Zhang Y, Jia WH, Zheng M (2013) KPNA2 promotes cell proliferation and tumorigenicity in epithelial ovarian carcinoma through upregulation of c-Myc and downregulation of FOXO3a. Cell Death Dis, 4:e745.

43. Gorlich D, Mattaj IW (1996) Nucleocytoplasmic transport. Science, 271(5255):1513-1518.

44. Gildemeister OS, Sage JM, Knight KL (2009) Cellular redistribution of Rad51 in response to DNA damage: novel role for Rad51C. J Biol Chem, 284(46):3194531952.

45. Stochaj U, Rassadi R, Chiu J (2000) Stress-mediated inhibition of the classical nuclear protein import pathway and nuclear accumulation of the small GTPase Gsp1p. FASEB J, 14(14):2130-2132.

46. Venkitaraman AR (2002) Cancer susceptibility and the functions of BRCA1 and BRCA2. Cell, 108(2):171-182.

47. Shen WH, Balajee AS, Wang J, Wu H, Eng C, Pandolfi PP, Yin Y (2007) Essential role for nuclear PTEN in maintaining chromosomal integrity. Cell, 128(1):157170.

48. Sorensen CS, Hansen LT, Dziegielewski J, Syljuasen RG, Lundin C, Bartek J, Helleday T (2005) The cell-cycle checkpoint kinase Chk1 is required for mammalian homologous recombination repair. Nat Cell Biol, 7(2):195-201.

49. Ma CX, Janetka JW, Piwnica-Worms H (2011) Death by releasing the breaks: CHK1 inhibitors as cancer therapeutics. Trends Mol Med, 17(2):88-96.

50. Bahassi EM, Ovesen JL, Riesenberg AL, Bernstein WZ, Hasty PE, Stambrook PJ (2008) The checkpoint kinases Chk1 and Chk2 regulate the functional associations between hBRCA2 and Rad51 in response to DNA damage. Oncogene, 27(28):3977-3985.

51. Rabik CA, Dolan ME (2007) Molecular mechanisms of resistance and toxicity associated with platinating agents. Cancer treatment reviews, 33(1):9-23.

52. Burma S, Chen BP, Chen DJ (2006) Role of non-homologous end joining (NHEJ) in maintaining genomic integrity. DNA Repair (Amst), 5(9-10):1042-1048.

53. Lieber MR (2008) The mechanism of human nonhomologous DNA end joining. $J$ Biol Chem, 283(1):1-5.

54. Moynahan ME, Cui TY, Jasin M (2001) Homology-directed dna repair, mitomycinc resistance, and chromosome stability is restored with correction of a Brca1 mutation. Cancer research, 61(12):4842-4850. 


\section{Figure legends:}

Figure 1: Western blotting and Immunohistochemical study. I): Testing the specificity of Rad51 antibody by Western Blot in MCF-7 cell line. II) Immunohistochemical expression of Rad51, A) Negative expression in invasive ductal/NST breast cancer case B): Positive cytoplasmic and nuclear expression in invasive NST BC case, and C); a case of invasive ductal carcinoma/NST showing nuclear Rad51 expression; all at magnification x200. III): Rad51 protein level detected by IHC in breast cancer on TMA. Each bar represents different class based on hereditary or sporadic BRCA1 and ER status. $\mathrm{n}=$ nuclear and $\mathrm{c}=$ cytoplasmic expression. Error bars represent Mean (SD) and was created on $\mathrm{H}$-score (ranges 0-300). $\mathbf{A}=$ sporadic cases [ER ${ }^{-}$ $\left.\& \mathrm{BRCA}^{-}\right]$vs. sporadic cases [ER $\left.{ }^{+} \& \mathrm{BRCA}^{+}\right], \mathbf{B}=$ sporadic cases [ER $\left.\& \mathrm{BRCA}^{-}\right]$vs. Hereditary cases [ER $]$, $\mathbf{C}=$ sporadic cases $\left[\mathrm{ER}^{-} \& \mathrm{BRCA} 1^{-}\right] \mathrm{vs}$. Hereditary cases $\left[\mathrm{ER}^{+}\right], \mathbf{D}=$ sporadic cases $\left[\mathrm{ER}^{+} \& \mathrm{BRCA1}^{+}\right] \mathrm{vs}$. Hereditary cases [ER $], \mathbf{E}=$ sporadic cases $\left[\mathrm{ER}^{+} \& \mathrm{BRCA}^{+}\right]$vs. Hereditary cases $\left[\mathrm{ER}^{+}\right]$, and $\mathbf{F}=$ Hereditary cases $\left[E R^{-}\right]$vs. Hereditary cases [ER $\left.{ }^{+}\right]$. ANOVA test was used for each marker within the classes.

Figure 2: The association between Rad51 and BCSS. $0=$ negative and $1=$ positive expression of Rad51. Where $\mathrm{n}=$ nuclear expression and $\mathrm{c}=$ cytoplasmic expression of Rad51 and $\mathrm{N}$; number of cases. Only patients who died from breast cancer were considered. A; association between nuclear expression of Rad51 and BCSS, whereas B; association between cytoplasmic Rad51 and BCSS. C; co-expression of nuclear and cytoplasmic of Rad51and its association with BCSS.

Figure 3: The association between Rad51 and BCSS and the effect of treatment on patient outcome. $\mathrm{N}$ : number of cases. Only patients died from breast cancer were considered. A: association between nuclear expression of Rad51 and BCSS based on chemotherapy in unselected cases and B: cytoplasmic expression of Rad51 and BCSS based on chemotherapy in unselected cases. C: nuclear expression of Rad51 and BCSS based on receiving/or not endocrine therapy in only ER-positive cases. D: cytoplasmic expression of Rad51 and BCSS based on receiving/or not endocrine therapy in only ER-positive cases.

Figure 4: Rad51 protein level detected by reverse phase protein microarray in different breast cancer cell lines. BRCA1 deficient HeLaSilenciX® cells and its control [BRCA1 and BRCA1.C respectively], MCF-7 and MDA-MB-436 (436) cells) were grown and lysed. Lysates were spotted onto nirocelulosed slides in duplicates using microarrayer. The slide was probed for RAD51 and GAPDH. Images of scanned nitrocellulose slides printed with extracted protein from cell lines and probed with the antibodies against the Rad51 and GAPDH. Five 2-fold dilutions of each sample were printed in duplicate. Background was subtracted and the intensity of each spot was normalised to its corresponding GAPDH level. Each (R) represents different passage of each sample; three different passages of each sample were used. Error bars represent Mean (SD). $\mathbf{A}=$ BRCA1 vs. BRCA1.C, $\mathbf{B}=$ BRCA1 vs. MDA-MB-436, $\mathbf{C}=$ BRCA1 vs. MCF-7, $\mathbf{D}=$ BRCA1.C vs. MDA-MB-436, $\mathbf{E}=$ BRCA1.C vs. MCF-7, and $\mathbf{F}=$ MDA-MB-436 vs. MCF-7.

Table legends: 
Table 1: Relationship between RAD51 co-localisation expression groups and clinicopathological parameters of the studied series.

Table 2: Associations between RAD51 co-localisation expression groups and DNA-damage repair biomarkers.

Table 3: Associations between RAD51 and the IHC expression of other biomarkers.

Table 4: Cox proportional hazards regression analyses for predictors of BCSS for RAD51 nuclear expression and RAD51 nucleocytoplasmic expression groups with other co-variables:

Supplementary Table 1: Sources, dilution, cut-offs point and pre-treatment conditions used of the antibodies of DNA damage sensing and repair markers used in this study 
Table 1: Relationship between RAD51 co-localisation expression groups and clinicopathological parameters of the studied series:

\begin{tabular}{|c|c|c|c|c|c|c|c|}
\hline \multirow{2}{*}{\multicolumn{2}{|c|}{ Parameters }} & \multicolumn{6}{|c|}{ RAD51 } \\
\hline & & \multirow{2}{*}{$\begin{array}{c}\mathbf{C}^{-} \mathbf{N}^{-} \\
\mathbf{N}(\%) \\
30(41.7)\end{array}$} & \multirow{2}{*}{ 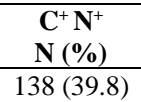 } & \multirow{2}{*}{$\begin{array}{c}\mathbf{C}^{+} \mathbf{N}^{-} \\
\mathbf{N}(\%) \\
177(25.7)\end{array}$} & \multirow{2}{*}{ 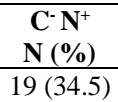 } & \multirow{3}{*}{$\frac{X^{2}}{25.5}$} & \multirow{3}{*}{$\begin{array}{c}\mathbf{P} \\
<0.0001\end{array}$} \\
\hline \multirow{2}{*}{ Tumour size } & $\leq 2 \mathrm{~cm}$ & & & & & & \\
\hline & $>2 \mathrm{~cm}$ & $42(58.3)$ & $209(60.2)$ & $512(74.3)$ & $36(65.5)$ & & \\
\hline \multirow{3}{*}{ Tumour grade } & 1 & $14(19.4)$ & $67(19.3)$ & $47(6.7)$ & $9(16.4)$ & \multirow{3}{*}{139.8} & \multirow{3}{*}{$<0.0001$} \\
\hline & 2 & $31(43.1)$ & $129(37.1)$ & $139(19.9)$ & $32(58.2)$ & & \\
\hline & 3 & $27(37.5)$ & $152(43.7)$ & $513(73.4)$ & $14(25.5)$ & & \\
\hline \multirow{3}{*}{ Tubules } & $\mathbf{1}$ & $3(4.5)$ & $21(6.2)$ & $14(2)$ & $1(1.9)$ & \multirow{3}{*}{44.6} & \multirow{3}{*}{$<0.0001$} \\
\hline & 2 & $29(43.3)$ & $117(34.6)$ & $160(23.4)$ & $24(44.4)$ & & \\
\hline & 3 & $35(52.2)$ & $200(59.2)$ & $509(74.5)$ & $29(53.7)$ & & \\
\hline \multirow{3}{*}{ Pleomorphism } & 1 & $1(1.5)$ & $9(2.7)$ & $1(0.1)$ & 0 & \multirow{3}{*}{104.5} & \multirow{3}{*}{$<0.0001$} \\
\hline & 2 & $32(47.8)$ & $142(42.1)$ & $139(20.4)$ & $32(59.3)$ & & \\
\hline & 3 & $34(50.7)$ & $186(55.2)$ & $541(79.4)$ & $22(40.7)$ & & \\
\hline \multirow{3}{*}{ Mitosis } & 1 & 28 (41.8) & $135(39.9)$ & $117(17.1)$ & $25(46.3)$ & \multirow{3}{*}{104.4} & \multirow{3}{*}{$<0.0001$} \\
\hline & 2 & $16(23.9)$ & $65(19.2)$ & $120(17.6)$ & $16(29.6)$ & & \\
\hline & 3 & $23(34.3)$ & $138(40.8)$ & $446(65.3)$ & $13(24.1)$ & & \\
\hline \multirow{3}{*}{$\begin{array}{l}\text { Axillary nodal } \\
\text { stage }\end{array}$} & 1 & $44(61.1)$ & $217(62.4)$ & $402(57.7)$ & $35(63.6)$ & \multirow{3}{*}{4.3} & \multirow{3}{*}{0.643} \\
\hline & 2 & $20(27.8)$ & $102(29.3)$ & $220(31.6)$ & $17(30.9)$ & & \\
\hline & 3 & $8(11.1)$ & $29(8.3)$ & $75(10.8)$ & $3(5.5)$ & & \\
\hline \multirow{6}{*}{ NPI } & Excellent & $9(12.5)$ & $45(13.1)$ & $28(4)$ & $7(12.7)$ & \multirow{6}{*}{110.6} & \multirow{6}{*}{$<0.0001$} \\
\hline & Good & $22(30.6)$ & $80(23.3)$ & $61(8.8)$ & $14(25.5)$ & & \\
\hline & Moderate 1 & $16(22.2)$ & $94(27.3)$ & $250(36)$ & $17(30.9)$ & & \\
\hline & Moderate 2 & $16(22.2)$ & $83(24.1)$ & $205(29.5)$ & $16(29.1)$ & & \\
\hline & Poor & $6(8.3)$ & $33(9.6)$ & $109(15.7)$ & $1(1.8)$ & & \\
\hline & Very poor & $3(4.2)$ & $9(2.6)$ & $41(5.9)$ & 0 & & \\
\hline \multirow{5}{*}{ Tumour type } & Invasive Ductal/NST & $35(49.3)$ & $188(54.7)$ & $535(77.3)$ & $17(31.5)$ & \multirow{5}{*}{137.6} & \multirow{5}{*}{$<0.0001$} \\
\hline & Invasive Lobular & $8(11.3)$ & $24(7.0)$ & $20(2.9)$ & $13(24.1)$ & & \\
\hline & Medullary-like & $1(1.4)$ & $5(1.5)$ & $21(3)$ & 0 & & \\
\hline & Mixed $^{+}$ & $21(29.6)$ & $109(31.7)$ & $98(14.2)$ & $22(40.7)$ & & \\
\hline & Other $^{++}$ & $6(8.5)$ & $18(5.2)$ & $18(2.6)$ & $2(3.7)$ & & \\
\hline
\end{tabular}


Table 2: Associations between RAD51 co-localisation expression groups and DNAdamage repair biomarkers.

\begin{tabular}{|c|c|c|c|c|c|c|c|}
\hline \multicolumn{8}{|c|}{ RAD51 } \\
\hline \multicolumn{2}{|l|}{ Parameters } & $\begin{array}{c}\mathbf{C}^{-} \mathbf{N}^{-} \\
\mathbf{N}(\%)\end{array}$ & $\begin{array}{l}\mathbf{C}^{+} \mathbf{N}^{+} \\
\mathbf{N}(\%)\end{array}$ & $\begin{array}{l}\mathbf{C}^{+} \mathbf{N}^{-} \\
\mathbf{N}(\%)\end{array}$ & $\begin{array}{c}\mathbf{C}^{-} \mathbf{N}^{+} \\
\mathbf{N}(\%)\end{array}$ & $X^{2}$ & $\mathbf{P}$ \\
\hline \multirow{2}{*}{ BRCA1 N } & Negative & $22(45.8)$ & $90(32.6)$ & $417(71.2)$ & $9(19.6)$ & \multirow{2}{*}{143.5} & \multirow{2}{*}{$<0.0001$} \\
\hline & Positive & $26(54.2)$ & $186(67.4)$ & $169(28.8)$ & $37(80.4)$ & & \\
\hline \multirow{2}{*}{ BRCA1 C } & Negative & $33(68.8)$ & $171(62.2)$ & $315(53.9)$ & $34(73.9)$ & \multirow{2}{*}{13.2} & \multirow{2}{*}{0.005} \\
\hline & Positive & $15(31.2)$ & $104(37.8)$ & $269(46.1)$ & $12(26.1)$ & & \\
\hline \multirow{2}{*}{ KU70/KU80 } & Negative & $24(36.9)$ & $24(7.5)$ & $58(9.7)$ & $11(23.4)$ & \multirow{2}{*}{55.0} & \multirow{2}{*}{$<0.0001$} \\
\hline & Positive & $41(63.1)$ & $294(92.5)$ & $542(90.3)$ & $36(76.6)$ & & \\
\hline \multirow{2}{*}{ DNA-PKcs } & Negative & $13(31)$ & $24(10.5)$ & $82(16.5)$ & $1(4)$ & \multirow{2}{*}{15.3} & \multirow{2}{*}{0.002} \\
\hline & Positive & $29(69)$ & $205(89.5)$ & $414(83.5)$ & $24(96)$ & & \\
\hline \multirow{2}{*}{ SMC6L1 C } & Negative & $26(55.3)$ & $84(34.7)$ & $131(26.4)$ & $8(28.6)$ & \multirow{2}{*}{19.5} & \multirow{2}{*}{$<0.0001$} \\
\hline & Positive & $21(44.7)$ & $158(65.3)$ & 365 (73.6) & $20(71.4)$ & & \\
\hline \multirow{2}{*}{ SMC6L1 N } & Negative & $17(36.2)$ & $75(31)$ & $171(34.5)$ & $5(17.9)$ & \multirow{2}{*}{4.2} & \multirow{2}{*}{0.3} \\
\hline & Positive & $30(63.8)$ & $167(69)$ & $325(65.5)$ & $23(82.1)$ & & \\
\hline \multirow{2}{*}{ BARD1 C } & Negative & $12(26.7)$ & $23(9.5)$ & $148(27.9)$ & $3(8.8)$ & \multirow{2}{*}{37.0} & \multirow{2}{*}{$<0.0001$} \\
\hline & Positive & $33(73.3)$ & $218(90.5)$ & $383(72.1)$ & $31(91.2)$ & & \\
\hline \multirow{2}{*}{ BARD1 N } & Negative & 42 (93.3) & $211(87.6)$ & $492(92.7)$ & $32(97)$ & \multirow{2}{*}{7.1} & \multirow{2}{*}{0.07} \\
\hline & Positive & $3(6.7)$ & $30(12.4)$ & $39(7.3)$ & $1(3)$ & & \\
\hline $\operatorname{ID4} \mathrm{C}$ & Negative & $41(57.7)$ & $113(32.3)$ & $236(34.3)$ & $24(43.6)$ & 102 & $<00001$ \\
\hline $104 \mathrm{C}$ & Positive & $30(42.3)$ & $237(67.7)$ & $452(65.7)$ & $31(56.4)$ & 19.2 & $<0.0001$ \\
\hline DTEN & Negative & $27(69.2)$ & $151(76.3)$ & $250(89)$ & $14(53.8)$ & 311 & $\leq 00001$ \\
\hline PIEN & Positive & $12(30.8)$ & $47(23.7)$ & $31(11)$ & $12(46.2)$ & 31.1 & $<0.0001$ \\
\hline CHE & Negative & $50(73.5)$ & $190(60.5)$ & $518(85.6)$ & $18(35.3)$ & 1144 & $\leq 00001$ \\
\hline CHKI N & Positive & $18(26.5)$ & $124(39.5)$ & $87(14.4)$ & $33(64.7)$ & 114.4 & $<0.0001$ \\
\hline CHK 1 & Negative & $18(26.5)$ & $21(6.7)$ & $37(6.1)$ & $15(29.4)$ & 610 & $<00001$ \\
\hline CHK & Positive & $50(73.5)$ & $292(93.3)$ & $568(93.9)$ & $36(70.6)$ & 61.0 & $<0.0001$ \\
\hline CHK? & Negative & $20(52.6)$ & $88(43.3)$ & $191(60.8)$ & $8(32)$ & 201 & $<00001$ \\
\hline CHIL & Positive & $18(47.4)$ & $115(56.7)$ & $123(39.2)$ & $17(68)$ & 20.1 & $<0.0001$ \\
\hline TM & Negative & $20(64.5)$ & $98(44.7)$ & $311(62.8)$ & $13(37.1)$ & 273 & $\leq 00001$ \\
\hline A IIVI & Positive & $11(35.5)$ & $121(55.3)$ & $184(37.2)$ & $22(62.9)$ & 27.3 & -0.0000 \\
\hline$\gamma \mathrm{H} 2 \mathrm{AX} \mathbf{N}$ & Negative & $4(11.1)$ & $8(3.6)$ & $93(19.2)$ & $1(3.7)$ & 342 & $<00001$ \\
\hline & Positive & $32(88.9)$ & $217(96.4)$ & $392(80.8)$ & $26(96.3)$ & 34.2 & $<0.0001$ \\
\hline H? $\mathrm{X} \mathrm{C}$ & Negative & $8(22.2)$ & $24(10.7)$ & $37(7.6)$ & $7(25.9)$ & 170 & 0001 \\
\hline & Positive & $28(77.8)$ & $201(89.3)$ & $448(92.4)$ & $20(74.1)$ & & \\
\hline MTA1 N & Negative & $19(46.3)$ & $82(34)$ & $250(48.2)$ & $10(30.3)$ & 161 & 0001 \\
\hline & Positive & $22(53.7)$ & $159(66)$ & $269(51.8)$ & $23(69.7)$ & 16.1 & 0.001 \\
\hline & Negative & $15(35.7)$ & $26(10.8)$ & $63(12.1)$ & $9(27.3)$ & & \\
\hline D1A C & Positive & $27(64.3)$ & $215(89.2)$ & $456(87.9)$ & $24(72.7)$ & 25.2 & $<0.0001$ \\
\hline
\end{tabular}


Table 3: Associations between RAD51 and the IHC expression of other biomarkers

\begin{tabular}{|c|c|c|c|c|c|c|c|}
\hline \multirow{2}{*}{\multicolumn{2}{|c|}{ Biomarkers }} & \multicolumn{6}{|c|}{ RAD51 } \\
\hline & & \multirow{2}{*}{$\begin{array}{c}\mathbf{C}^{-} \mathbf{N}^{-} \\
\mathbf{N}(\%) \\
23(33.3)\end{array}$} & \multirow{2}{*}{ 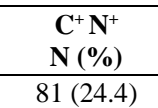 } & \multirow{2}{*}{$\begin{array}{c}\mathbf{C}^{+} \mathbf{N}^{-} \\
\mathbf{N}(\boldsymbol{\%}) \\
387(56.7)\end{array}$} & \multirow{2}{*}{$\begin{array}{c}\mathbf{C}^{-} \mathbf{N}^{+} \\
\mathbf{N}(\%) \\
5(9.4)\end{array}$} & \multirow{3}{*}{$\begin{array}{c}\boldsymbol{X}^{2} \\
126.5\end{array}$} & \multirow{3}{*}{$\begin{array}{c}\mathbf{P} \\
<0.0001\end{array}$} \\
\hline \multirow{2}{*}{ ER } & Negative & & & & & & \\
\hline & Positive & $46(66.7)$ & $251(75.6)$ & $295(43.3)$ & $48(90.6)$ & & \\
\hline \multirow{2}{*}{ PgR } & Negative & $30(46.9)$ & $127(38.7)$ & $426(65.4)$ & $6(12.5)$ & \multirow{2}{*}{100.4} & \multirow{2}{*}{$<0.0001$} \\
\hline & Positive & $34(53.1)$ & $201(61.3)$ & $225(34.6)$ & $42(87.5)$ & & \\
\hline \multirow{2}{*}{ Triple Negative } & Negative & $52(78.8)$ & $284(86.3)$ & $397(60.5)$ & $49(94.2)$ & \multirow{2}{*}{88.3} & \multirow{2}{*}{$<0.0001$} \\
\hline & Positive & $14(21.2)$ & $45(13.7)$ & $259(39.5)$ & $3(5.8)$ & & \\
\hline \multirow{2}{*}{ CK5/6 } & Negative & $46(86.8)$ & $235(83.9)$ & $376(67.5)$ & $41(95.3)$ & \multirow{2}{*}{42.2} & \multirow{2}{*}{$<0.0001$} \\
\hline & Positive & $7(13.2)$ & $45(16.1)$ & $181(32.5)$ & $2(4.7)$ & & \\
\hline \multirow{2}{*}{ CK17 } & Negative & $51(94.4)$ & $215(84.6)$ & $463(79.3)$ & $36(90)$ & \multirow{2}{*}{11.5} & \multirow{2}{*}{0.009} \\
\hline & Positive & $3(5.6)$ & $39(15.4)$ & $121(20.7)$ & $4(10)$ & & \\
\hline \multirow{2}{*}{ BLBC } & Negative & $49(87.5)$ & $278(88)$ & $406(68.1)$ & $45(93.8)$ & \multirow{2}{*}{58.0} & \multirow{2}{*}{$<0.0001$} \\
\hline & Positive & $7(12.5)$ & $38(12)$ & $190(31.9)$ & $3(6.2)$ & & \\
\hline \multirow{2}{*}{ P53 } & Negative & $47(75.8)$ & $233(71)$ & $370(55.1)$ & $40(80)$ & \multirow{2}{*}{37.0} & \multirow{2}{*}{$<0.0001$} \\
\hline & Positive & $15(24.2)$ & $95(29)$ & $302(44.9)$ & $10(20)$ & & \\
\hline \multirow[b]{2}{*}{ Ki67 } & Negative & $32(55.2)$ & $139(50)$ & $149(24.1)$ & $22(53.7)$ & \multirow[b]{2}{*}{77.2} & \multirow[b]{2}{*}{$<0.0001$} \\
\hline & Positive & $26(44.8)$ & $139(50)$ & $469(75.9)$ & $19(46.3)$ & & \\
\hline \multirow[t]{2}{*}{$\mathbf{P 2 7}$} & Negative & $12(44.4)$ & $34(28.6)$ & $203(59.2)$ & $8(34.8)$ & \multirow{2}{*}{36.1} & \multirow{2}{*}{$<0.0001$} \\
\hline & Positive & $15(55.6)$ & $85(71.4)$ & $140(40.8)$ & $15(65.2)$ & & \\
\hline \multirow{2}{*}{ KPNA2 } & Negative & 35 (71.4) & $121(54.0)$ & $20(64.5)$ & $187(37.4)$ & 270 & O $00 \Omega$ \\
\hline & Positive & $14(28.6)$ & $103(46.0)$ & $11(35.5)$ & $313(62.6)$ & 37.9 & $<0.0001$ \\
\hline $\begin{array}{l}\mathrm{N}=\text { number of ca } \\
\text { (ER-, PgR- and } \\
\text { and/or CK17. Tl }\end{array}$ & $\begin{array}{l}\text { cytoplas } \\
\text { BLBC= } \\
\text { points }\end{array}$ & $\begin{array}{l}\mathrm{N}=\text { nucle } \\
\text { like breas } \\
\text { tivity we }\end{array}$ & $\begin{array}{l}\text { ission. ER } \\
\text { r defined }\end{array}$ & gen rece & $\begin{array}{l}\mathrm{R}=\text { Proge } \\
\text { ositive ex }\end{array}$ & cri & $\begin{array}{l}\text { e negative } \\
\text { or CK14 }\end{array}$ \\
\hline
\end{tabular}


Table 4: Cox proportional hazards regression analyses for predictors of BCSS for RAD51 nuclear expression and RAD51 nucleocytoplasmic expression groups with other co-variables:

\begin{tabular}{|c|c|c|c|c|c|c|c|c|c|}
\hline \multirow{3}{*}{ Parameters } & \multirow{3}{*}{ P-value } & \multicolumn{3}{|c|}{ Hazard Ratio (HR) } & \multirow[t]{3}{*}{ Parameters } & \multirow[t]{3}{*}{ P-value } & \multicolumn{3}{|c|}{ Hazard Ratio } \\
\hline & & \multirow{2}{*}{ HR } & \multicolumn{2}{|c|}{$95 \% \mathrm{CI}$} & & & \multirow[t]{2}{*}{ HR } & \multicolumn{2}{|c|}{$95 \% \mathrm{CI}$} \\
\hline & & & Lower & Upper & & & & Lower & Upper \\
\hline RAD51 N & 0.004 & 0.733 & 0.559 & 0.960 & RAD51N/C & 0.08 & 1.183 & 0.980 & 1.428 \\
\hline $\begin{array}{c}\text { Tumour } \\
\text { Size }\end{array}$ & 0.022 & 1.465 & 1.057 & 2.032 & $\begin{array}{c}\text { Tumour } \\
\text { Size }\end{array}$ & 0.017 & 1.491 & 1.075 & 2.067 \\
\hline $\begin{array}{c}\text { Tumour } \\
\text { Grade }\end{array}$ & $<0.0001$ & 1.923 & 1.536 & 2.408 & $\begin{array}{c}\text { Tumour } \\
\text { Grade }\end{array}$ & $<0.0001$ & 1.992 & 1.590 & 2.495 \\
\hline $\begin{array}{l}\text { Tumour } \\
\text { Stage }\end{array}$ & $<0.0001$ & 2.133 & 1.775 & 2.562 & $\begin{array}{c}\text { Tumour } \\
\text { Stage }\end{array}$ & $<0.0001$ & 2.126 & 1.767 & 2.557 \\
\hline $\begin{array}{l}\text { Chemo- } \\
\text { therapy }\end{array}$ & 0.008 & 0.632 & 0.450 & 0.887 & $\begin{array}{l}\text { Chemo- } \\
\text { therapy }\end{array}$ & 0.007 & 0.621 & 0.440 & 0.877 \\
\hline $\begin{array}{c}\text { Endocrine } \\
\text { therapy }\end{array}$ & 0.011 & 0.734 & 0.577 & 0.933 & $\begin{array}{c}\text { Endocrine } \\
\text { therapy }\end{array}$ & 0.004 & 0.702 & 0.550 & 0.896 \\
\hline
\end{tabular}


Supplementary table 1: Sources, dilution, cut-off points and pre-treatment conditions used of the primary antibodies used in this study:

\begin{tabular}{|c|c|c|c|c|c|c|}
\hline Antibody & Clone & Source & $\begin{array}{l}\text { Dilution } \\
\text { IHC }\end{array}$ & $\begin{array}{c}\text { Dilution } \\
\text { W.B } \\
\text { RPPA } \\
\end{array}$ & $\begin{array}{c}\text { Cellular } \\
\text { localisation }\end{array}$ & Cut-off point \\
\hline \multicolumn{7}{|c|}{ DNA damage sensors and signal transducers } \\
\hline ATM & $\mathrm{Ab} 32420$ & Abcam & $\begin{array}{l}1: 100 \\
\text { overnight }\end{array}$ & $\begin{array}{l}1: 1,000 \\
1: 500\end{array}$ & Nuclear & $\geq 75 \%$ \\
\hline CHK1 (phospho S345) & Ab58567 & Abcam & $1: 1501 \mathrm{~h}$ & $\begin{array}{l}1: 1,000 \\
1: 6,000\end{array}$ & Nuclear/cytoplasmic & $\begin{array}{l}\mathrm{H} \text {-score } \geq 20 \text { for nuclear, and } \geq 80 \\
\text { for cytoplasmic. }\end{array}$ \\
\hline CHK2 & $\mathrm{Ab} 47433$ & Abcam & $1: 1001 \mathrm{~h}$ & $\begin{array}{l}1: 500 \\
1: 6,000\end{array}$ & Nuclear & Median.(H-score $\geq 105$ ) \\
\hline$\gamma \mathrm{H2AX}$ (phospho S139) & $\mathrm{Ab} 22551$ & Abcam & $1: 6001 \mathrm{~h}$ & $\begin{array}{l}1: 2,000 \\
1: 1000\end{array}$ & Nuclear/cytoplasmic & $\begin{array}{l}\mathrm{H} \text {-score } \geq 40 \text { for nuclear, and } \geq 120 \\
\text { for cytoplasmic. }\end{array}$ \\
\hline \multicolumn{7}{|c|}{ Homologous recombination DNA repair markers } \\
\hline BARD1 & $\begin{array}{l}\text { NBP1- } \\
19636\end{array}$ & $\begin{array}{l}\text { Novus } \\
\text { Biologicals }\end{array}$ & $1: 501 \mathrm{~h}$ & $\begin{array}{l}\text { NT } \\
1: 200\end{array}$ & Nuclear/cytoplasmic & $\begin{array}{l}\mathrm{H} \text {-score }>0 \text { for nuclear. And } \geq 130 \\
\text { for cytoplasmic }\end{array}$ \\
\hline SMC6L1 & AB57759 & Abcam & $1: 100 \mathrm{lh}$ & $\begin{array}{l}1: 1,000 \\
1: 250 \\
\end{array}$ & Nuclear/cytoplasmic & $\begin{array}{l}\mathrm{H} \text {-score }>240 \text { for nuclear, and } \\
\geq 230 \text { for cytoplasmic. }\end{array}$ \\
\hline \multicolumn{7}{|c|}{ Non homologous end joining DNA repair markers } \\
\hline KU70/KU80 & Ab3108 & Abcam & $1: 25001 \mathrm{~h}$ & $\begin{array}{l}1: 1,000 \\
1: 500\end{array}$ & Nuclear & $\geq 90 \mathrm{H}$-score. \\
\hline DNA-PK & $3 \mathrm{H} 6$ & $\begin{array}{l}\text { Cell } \\
\text { signalling }\end{array}$ & $1: 281 \mathrm{~h}$ & $\begin{array}{l}1: 2,000 \\
1: 150 \\
\end{array}$ & Nuclear & $\geq 150 \mathrm{H}$-score. \\
\hline \multicolumn{7}{|c|}{ BRCA1 Down Regulators Proteins } \\
\hline MTA1 & Ab84136 & Abcam & $1: 2001 \mathrm{~h}$ & $\begin{array}{l}\text { NT } \\
\text { NT }\end{array}$ & Nuclear/cytoplasmic & $\begin{array}{l}\mathrm{H} \text {-score } \geq 50 \text { for nuclear and } \geq 120 \\
\text { for cytoplasmic }\end{array}$ \\
\hline ID4 & Ab77345 & Abcam & $1: 1001 \mathrm{~h}$ & $\begin{array}{l}\text { NT } \\
\text { NT }\end{array}$ & Nuclear/cytoplasmic & $\begin{array}{l}\mathrm{H} \text {-score } \geq 12 \text { for nuclear and } \geq 100 \\
\text { for cytoplasmic. }\end{array}$ \\
\hline \multicolumn{7}{|c|}{ Tumour Suppressor proteins } \\
\hline PTEN & $\begin{array}{l}\text { MMAC1 } \\
\text { Ab-4 (Clone } \\
\text { 17.A) }\end{array}$ & $\begin{array}{l}\text { Thermo- } \\
\text { scientific }\end{array}$ & $1: 501 \mathrm{~h}$ & $\begin{array}{l}\mathrm{NT} \\
1: 500\end{array}$ & Nuclear & $\mathrm{H}$-score $\geq 1$ \\
\hline \multicolumn{7}{|c|}{$\begin{array}{l}\text { - All the antibodies were pre-treated in citrate antigen retrieval } \mathrm{pH}=6.0 \text { in microwave for } 20 \text { minutes and stained on TMA. NT= not tested. IHC= } \\
\text { immunohistochemistry. WB= western blot. RPPA= Reverse Phase Protein Microarray. } \\
\text { The Novolink }{ }^{\mathrm{TM}} \text { Max Polymer Detection System from Leica Biosystems (Leica, Newcastle, UK) was used as a detection kit for all these } \\
\text { antibodies. }\end{array}$} \\
\hline
\end{tabular}


I)
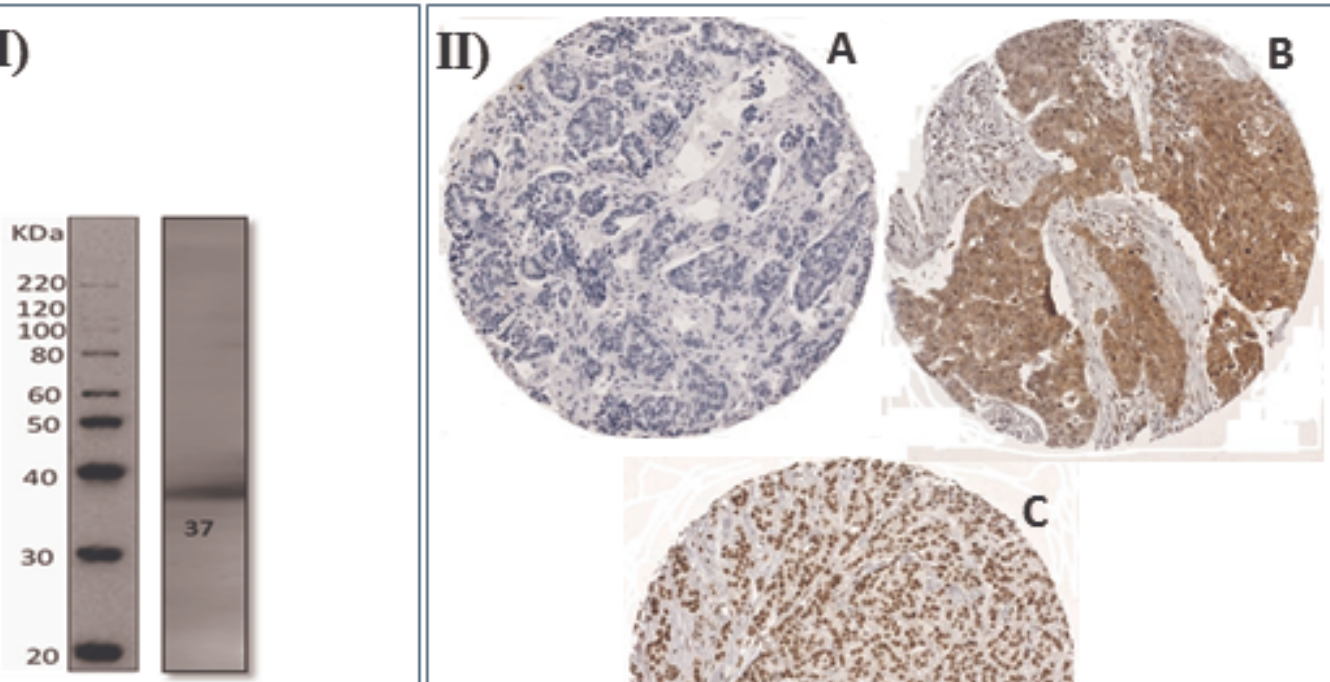

Rad51

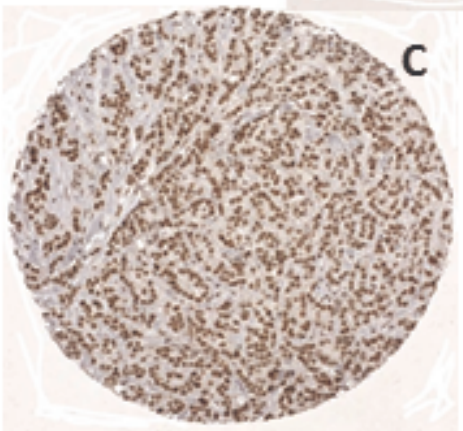

III)
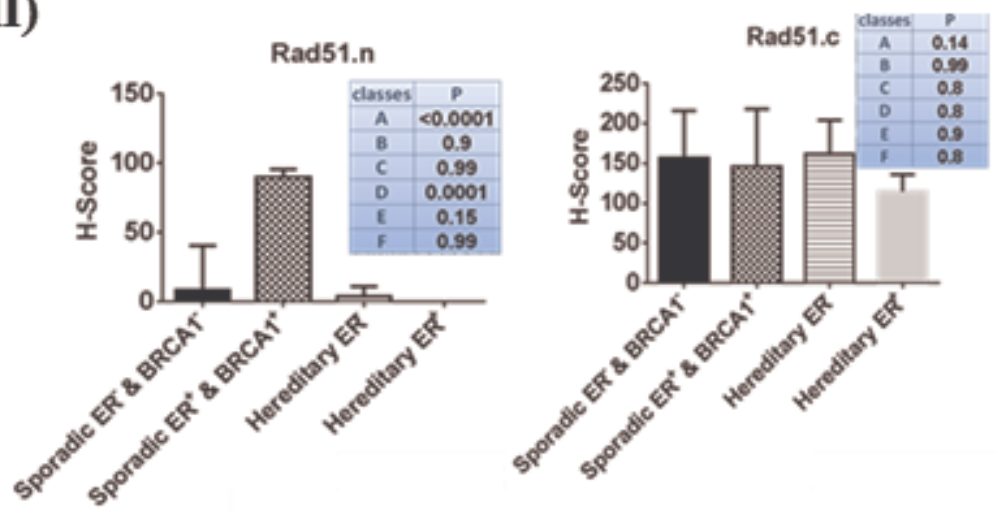


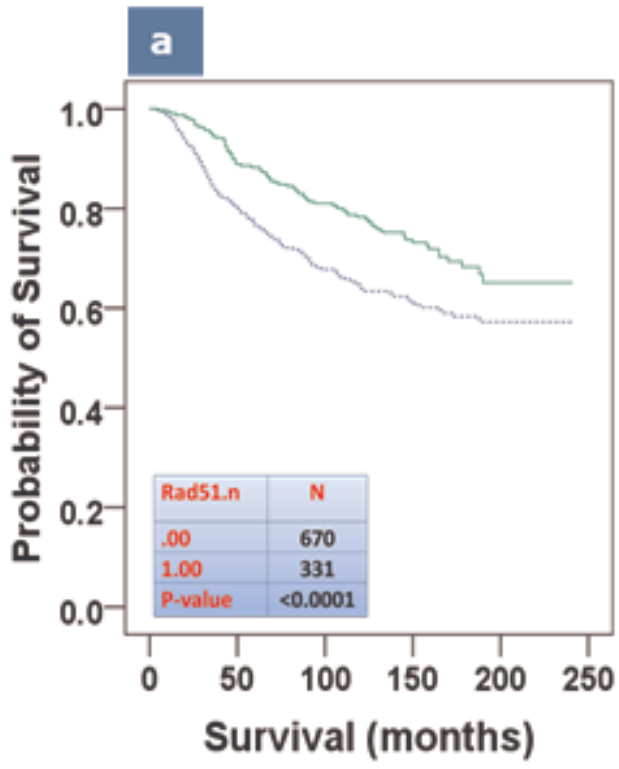

Rad51.n

... 00

$\neg 1.00$
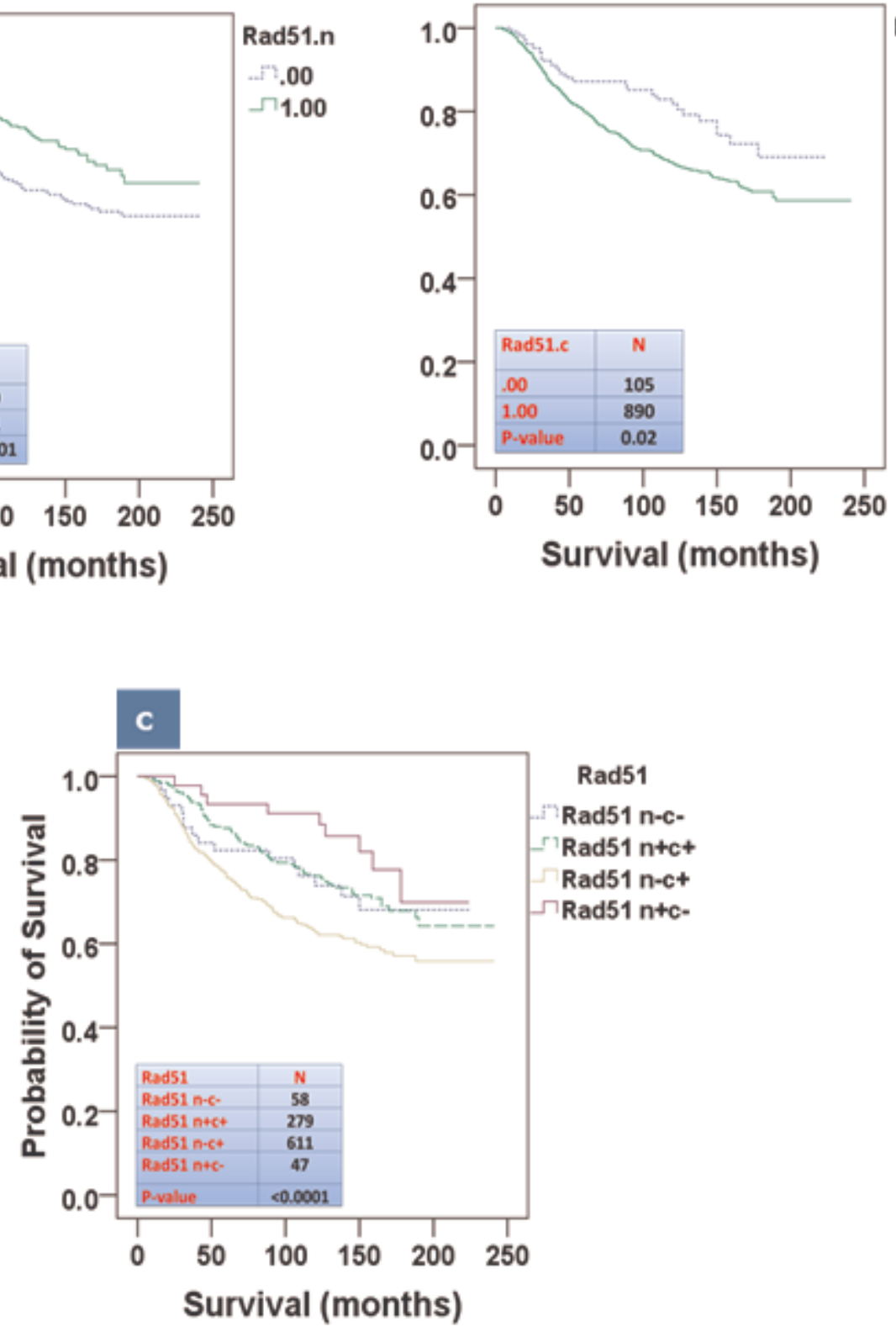

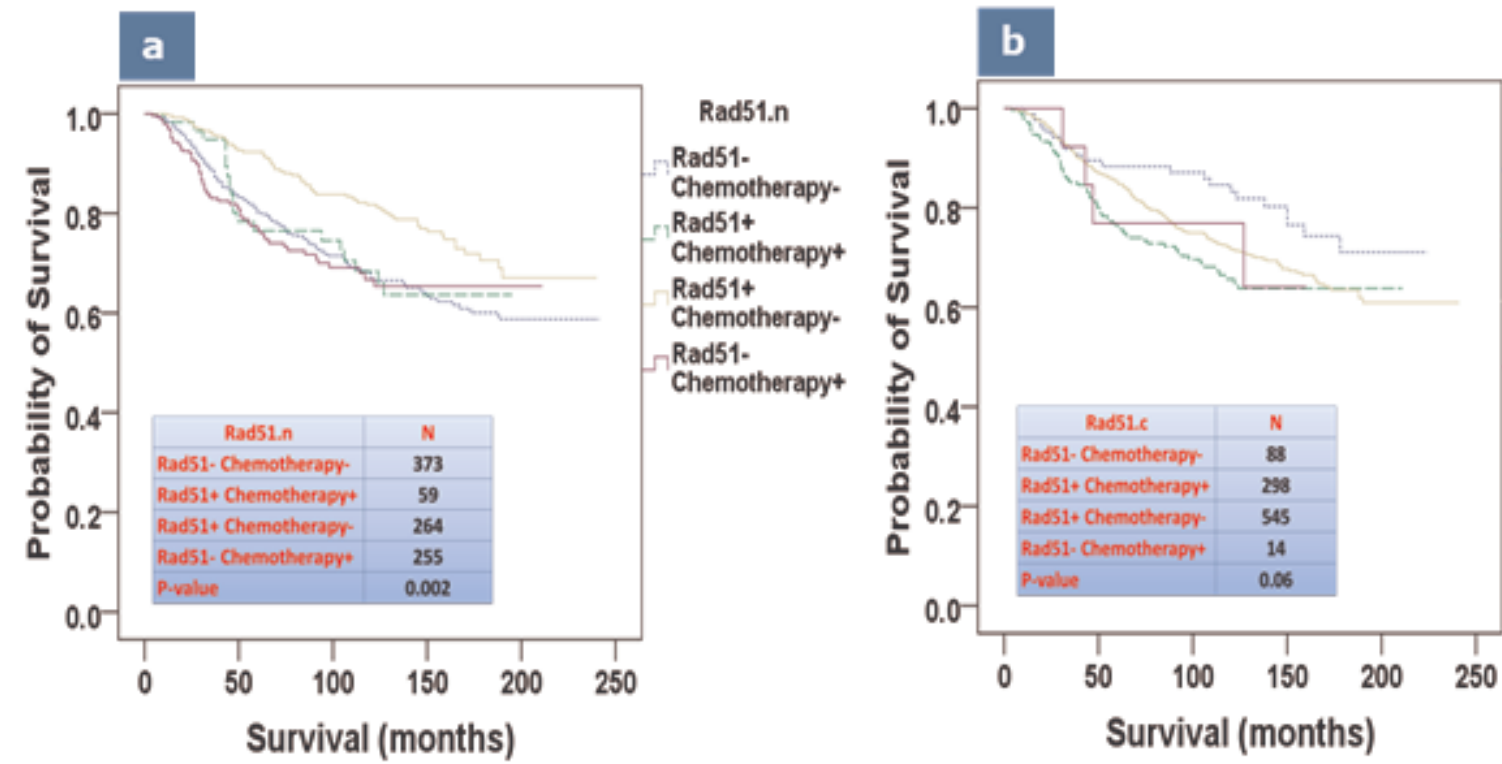

Rad51.c

Rad51-

Chemotherapy-

Rad51+

Chemotherapy+

Rad51+

Chemotherapy-

Rad51.

Chemotherapy+
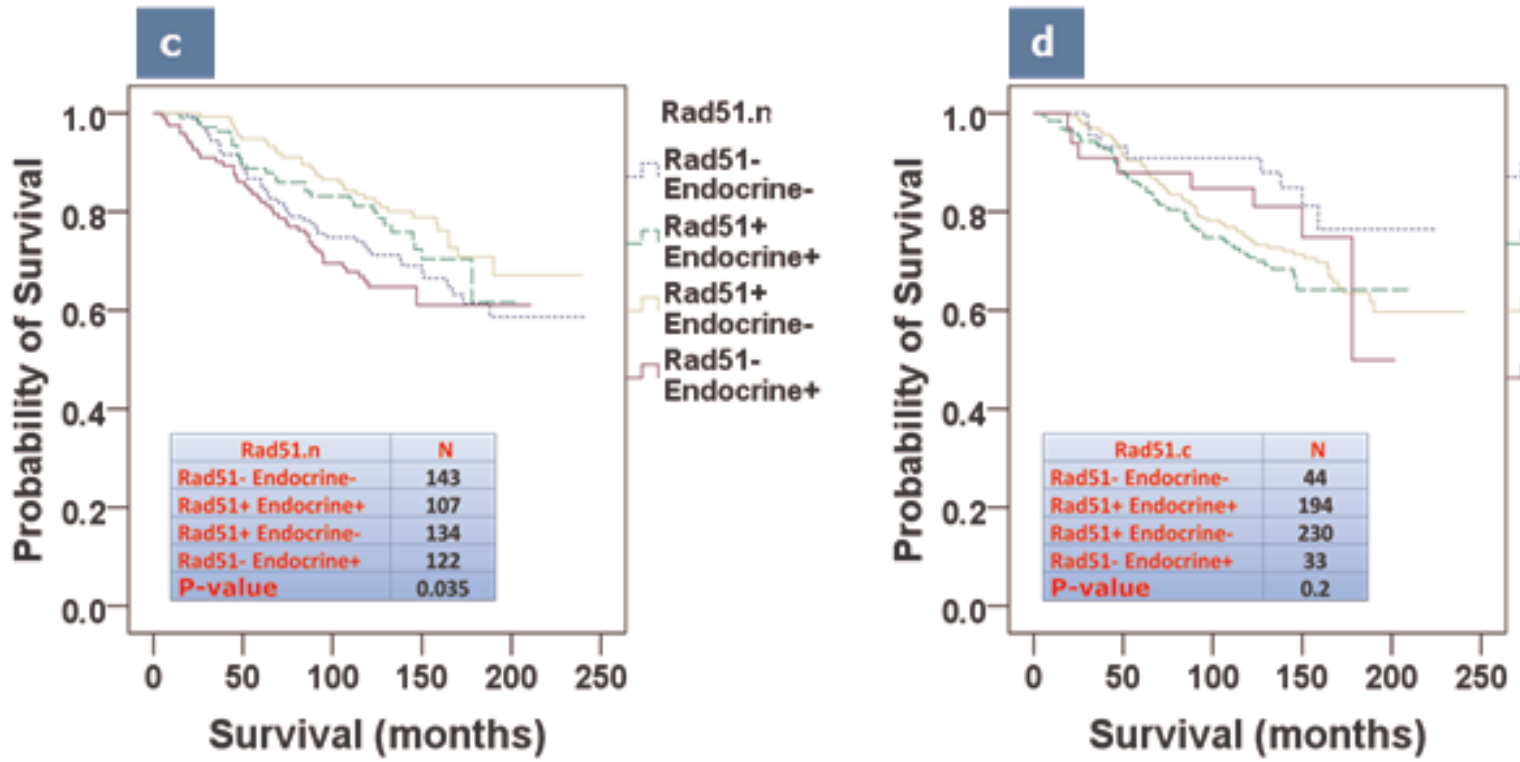

Rad51.c

Rad51.n

Rad51-

Endocrine-

Rad51+

Endocrine+

Rad51+

Endocrine-

Rad51-

Endocrine+

Survival (months)

Rad51.

Chemotherapy-

Rad51+

Chemotherapy+

Rad51+

Chemotherapy-

Rad51.

Chemotherapy+

Rad51-

Endocrine-

Rad51+

Endocrine+

Rad51+

Endocrine-

Rad51-

Endocrine+ 


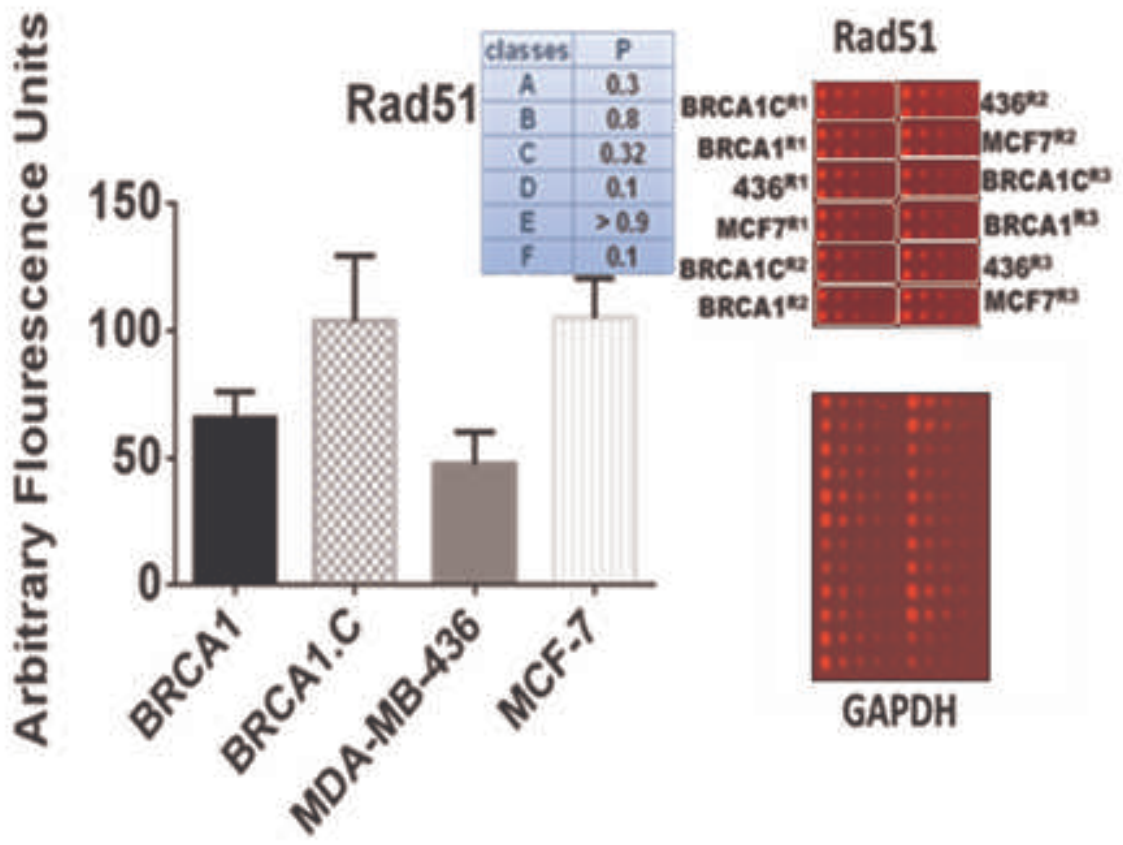

